\title{
Cultural-Historic Resources as a Factor of Entrance Tourism Development in Finland
}

\author{
Rysayeva M. A. ${ }^{1}$, Bagautdinova N. G. ${ }^{2} \&$ Ziganshin I. I. ${ }^{1}$ \\ ${ }^{1}$ Institute of Economics, Management and Law, Kazan, Russian Federation \\ ${ }^{2}$ Kazan Federal University, Institute of Management, Economics and Finance, Kazan, Russia \\ Correspondence: Rysayeva M. A., Institute of Economics, Management and Law, 420111 Kazan, Russian \\ Federation.
}

Received: March 10, 2015 Accepted: March 31, 2015 Online Published: April 30, 2015

doi:10.5539/ass.v11n11p198 URL: http://dx.doi.org/10.5539/ass.v11n11p198

\begin{abstract}
The article is devoted to the complex evaluation of the venue of cultural-historic heritage of Finland, in order to prove its tourist attraction and inclusion into the touristic routes around the country. The cultural-historic venue are classified thematically, their territorial location and ranging in Finland are shown.
\end{abstract}

Keywords: cultural resources, Finland, type of cultural-historic venue, cities of Finland

\section{Introduction}

According to World Tourism Organization (UNWTO), cultural-educational motivation is the leading motivation in the structure of international tourist trips, constituting $37 \%$ of the world tourism. UNWTO predicts the further growth of cultural-educational tourism up to $15 \%$ a year (http://www. unwto.org).

The cultural-educational tourism is based on social-cultural environment - traditions and customs, history and archeology, features of everyday and economic functioning. All over the world, the cultural venues and cities, rich in architectural, historic and archeological heritage, are popular with tourists (Murphy \& Boyle, 2006; Lindsay, 2009; Valle, Guerreiro, Mendes, \& Silva, 2011; Remoaldo, Ribeiro, Vareiro, \& Santos, 2014).

The nearing with Russia tourist destination - Finland - possesses the rich cultural-historic potential. Alongside with natural venues, the important factor of Finland's attraction for foreign tourists is the unique historical-cultural potential, including numerous material and spiritual monuments (more than 389 historical venues of major interest for tourists). It should be also noted that the modern Finnish capital - Helsinki - and its first capital - Turku - were awarded the title of the cultural capital of Europe in 2000 and 2013 respectively.

Thus, the issues of complex evaluation of the cultural-historical resources of Finland, their ranging by the volume of cultural-historical tourist-recreation potential of the regions, are of great importance.

Finland, or, as the Finns themselves call it, Suomi is situated between 60 and 70 degrees NL. The northern part is situated behind the North Polar circle. The area of Finland is 338000 square kilometers - it is the seventh largest country in Europe. The length of the country is $1160 \mathrm{~km}$, its width is $540 \mathrm{~km}, 10 \%$ of the area is covered with water, $69 \%$ - with forests. The border with Sweden is $586 \mathrm{~km}$ long, with Norway - $716 \mathrm{~km}$, with Russia - 1269 $\mathrm{km}$.

There are 108 towns in Finland, and each of them is a treasury of rich history, culture and traditions (Honkanen, 2002; Kantanen \& Tikkanen, 2006; Purhonen, Gronow, \& Rahkonen, 2011).

Even towns with less than 50 thousand people can have plenty of cultural venues. For example, the historical center of Raahe in the north of Finland, with population of less than 25 thousand people, is one of the 10 well-preserved ancient Finnish wooden towns, housing 5 large museums and ancient churches.

Finland wonderfully represents the harmonious combination of dynamic progress in large countries (Helsinki, Tampere, Turku, \& Oulu) with the calm and secluded rest in rural areas (Porvoo, Hämeenlinna, \& Hanko).

Finnish culture during the centuries of its existence was strongly influenced by such European countries as Denmark, Sweden, Russia, and Germany. Large cultural diversity can be found in various regions of Finland. The southern part of the country is close to European heritage, while the polar regions of Finland (Lapland) are 
linked with Sami cultural tradition and Northern people. This fact determines the variety and diversity of the cultural and historic resources of the country: from outdoor museums and Stone Age settlements to the Sami hut museum and Kalevala village.

One of the practical aspects of the complex evaluation of the country's cultural-historical heritage was implemented by the authors in July 2013 in the Helsinki region. Individual (independent) tourists were questioned in order to collect information about their preferences, motivations and the most visited sites. The choice of individual tourists was due to their independence of excursion programs and larger variety of the sites they visit.

Respondents included visitors from China, Russia, Germany, Canada, Japan, Estonia, and the local citizens. 187 tourists were polled. The method was focused structured interview with open questions:

- age of the tourist;

- occupation;

- country of origin;

- motivation of visit;

- most visited sites of the capital.

The local citizens and the Russians appeared to be the most open for the dialogue; the Asians were more reserved and cautious.

The poll showed the following results:

- The average age of tourists was 33 years;

- Occupation is varied (students, white-collar workers, self-employed people, pensioners);

- Main countries are Russia, China, and Japan.

The motivations for visit were (in descending order):

a) to get acquainted with cultural and historic monuments of Finland, its history, customs and traditions;

б) rest and recreation;

в) ecologically pure natural environment;

г) obtaining new experience and impressions.

According to the poll results, the most visited sites of the Finnish capital are (in descending order):

- Esplanadin puisto,

- Suomenlinna,

- Kauppatori,

- Helsinki City Centre Elielinaukio,

- Heureka Museum,

- Seurasaari outdoor museum,

- Linnanmäki entertainment park,

- Sibelius Monument,

- Töölönlahti Bay,

- Senaatintori,

- Serena aqua-park,

- Temppeliaukio church,

- Korkeasaari zoo,

- Design District Helsinki,

- Sealife aqua-center,

- Riihitien talo, the house by the Finnish architect Alvar Aalto,

- Helsinki Opera House.

The quantitative indicators of tourists preferences are shown in Figure 1. 


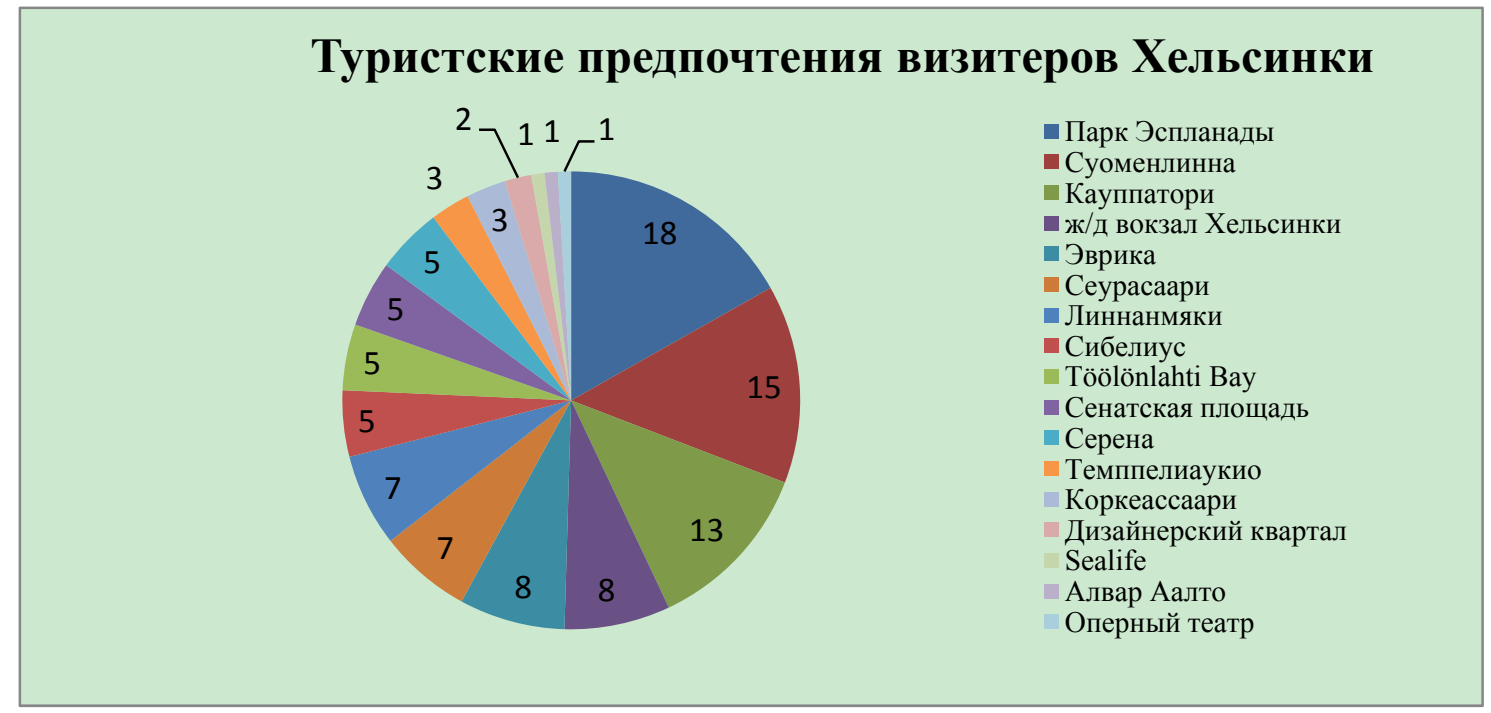

Figure 1. Top venues visited by independent tourists in Helsinki (number of people)

Figure 1 shows that from 17 most attractive sites, 16 are of cultural-historical and social character. This is confirmed by the opinions of tourists, who listed the major motives of choosing a tourist destination.

It is notable that 7 out of 17 venues in Fig. 1 are either included into the excursion programs offered by the Finnish tour operators (Suomenlinna, Senaatintori, Sibelius Monument), or are visited independently due to their compact location in Helsinki (Esplanadin puisto, Linnanmäki).

Finnish towns are quite compact, almost all their sites are located within a walk, others can be easily accessed by public transport.

Out of 1046 tourist venues systematized by their functioning, 389 venues are of cultural-historical character, which include:

- Cities and municipalities;

- Museums and museum complexes;

- Venues of cult architecture (churches, temples, cathedrals, monasteries);

- Ethnographic venues of culture and everyday life (outdoor museums, museums of national costume, peasants' life, ethnographic villages, etc.);

- Venues of medieval architecture (castles, fortresses, towers, ruins, palaces, Old Town);

- Monuments of industrial architecture (mills, plants, industrial zones, workshops, dumps, mines);

- Venues of city construction and architecture (city halls, city districts, bridges, sculpture parks and gardens, stations, squares).

The statistical and qualitative analysis of the cultural-historical venues allowed to systematize them by the above-mentioned groups (Table 1).

Table 1. Cultural-historical venues of Finland

\begin{tabular}{llc}
\hline$№$ & Type of cultural-historical venue & Number of venues \\
\hline 1. & City & 108 \\
2. & Municipality (community) & 336 \\
3. & Museums and museum complexes & 189 \\
4. & Venues of cult architecture (churches, temples, cathedrals, monasteries, chapels) & 116 \\
5. & Ethnographic venues of culture and everyday life & 25 \\
6. & Venues of medieval architecture (castles, fortresses, ruins, Old Town) & 21 \\
7. & Monuments of industrial architecture (mills, plants, mines, tunnels) & 7 \\
8. & Venues of city construction and architecture (city halls, city districts, bridges, & 31 \\
\hline
\end{tabular}


Having given the quantitative analysis of the cultural-historic venues of Finland, we should also present the qualitative evaluation, to show their tourist attraction and define the character of their efficient implementation for the development of entrance tourism.

\section{Cities and municipalities}

As of January 1, 2012, there were 108 towns in Finland. 19 regions are divided into 72 districts, which are divided into 336 communities (municipalities). The smallest administrative-territorial unit of the country is a community, but since 1995 the rural and urban communities are not distinguished by law, and any community can call itself a town. This legislative norm is supported by the fact that municipalities often act as a town and a community simultaneously. The population of the Finnish communities varies from 5-20 thousand people, which allows them to be legally called towns or town-municipalities (Joutsa, Loimaa, Inari, Saarijarvi, etc). This fact destroys the stereotype that small town have no tourist venues and cannot offer comfortable conditions for the tourists.

Table 2 shows the examples of small Finnish municipalities and towns having great recreation potential and prospects of use for tourist purposes.

Table 2. Tourist-recreational potential of towns and municipalities of Finland

\begin{tabular}{ccccc}
\hline $\begin{array}{c}\text { city / } \\
\text { municipality }\end{array}$ & Region & $\begin{array}{c}\text { Population } \\
\text { thousand } \\
\text { people) }\end{array}$ & $\begin{array}{c}\text { Distance from the } \\
\text { nearest airport }\end{array}$ & Tourist venues \\
\hline Jamsa & $\begin{array}{c}\text { Central } \\
\text { Finland }\end{array}$ & 22 & Jyvaskyla $(70 \mathrm{~km})$ & $\begin{array}{c}\text { Historic findings of the Viking epoch; Museum } \\
\text { of Finnish bath; Ski resort Himos (17 slopes) }\end{array}$ \\
\hline Hankasalmi & $\begin{array}{c}\text { Central } \\
\text { Finland }\end{array}$ & 5500 & Jyvaskyla $(20 \mathrm{~km})$ & $\begin{array}{c}\text { Ski resort with 12 slopes; } \\
\text { Annual winter festival of under-ice fishing; } \\
\text { The most spacious church Hankasalmen. }\end{array}$ \\
\hline Pyhajarvi & $\begin{array}{c}\text { Northern } \\
\text { Finland }\end{array}$ & 6000 & Kajaani $(107 \mathrm{~km})$ & $\begin{array}{c}\text { Annual festival of sunlight and twilight; } \\
\text { The deepest zinc mine-museum in Europe }\end{array}$ \\
\hline Kemijarvi & $\begin{array}{c}\text { Northern } \\
\text { Finland }\end{array}$ & 8000 & Kajaani $(58 \mathrm{~km})$ & $\begin{array}{c}\text { Annual (since 1989) international championship } \\
\text { in marsh football; } \\
\text { Finland } \\
\text { 12 meters high waterfall Komulanköngäs }\end{array}$ \\
\hline
\end{tabular}

The European definition of a town (not less than 50 thousand citizens, with population density of 500 people per square kilometer) corresponds in Finland only to Helsinki (603 thousand), Espoo (236 thousand), Tampere (213 thousand), Vantaa (200 thousand), Turku (182 thousand), Jyvaskyla (133 thousand), Lahti (102 thousand). All these towns, except Lahti, have an airport and are connected by regular flights with the capital.

The largest Finnish towns, namely Espoo, Vantaa, and Lahti, as well as the capital, are situated in the south of the country, where a quarter of the population lives. This is largely due to the favorable climatic conditions, with mild winter and warm summer; transport availability of the satellite towns and Helsinki and the main airport of the country.

Helsinki with its satellite towns is not only the capital but also the largest city, the center of tourism and cultural life of the country. Trips to Suomi, as a rule, include the capital region, where there are over 80 museums, Suomenlinna fortress included into the UNESCO World Heritage List, Senaatintori, which is the historic center of the city, Temppeliaukio church, and the annual world-scale events.

The border towns of Finland play an important role in entrance tourism: Lappeenranta, Imatra, Kotka, Kouvola, Hamina are actively visited by the Russian tourists (Furmanov, Balaeva, \& Predvoditeleva, 2012). The offer excellent shopping and one-day tours with visits to the shops or an aqua-park.

The large towns Tampere, Turku, Kuopio, Savonlinna, located in the south-west and east of the country, are still less visited by tourists, though they possess a great recreational and cultural-historic significance with plenty of aqua-parks and thematic museums: from the espionage museum to Mumintroll museum, to Cathedral in the oldest town of the country - Turku (Kostiainen \& Sotarauta, 2010).

In the very center of Finland there is Jyvaskyla - a university town with rich culture, the surroundings of which are abound with monuments of Finnish wooden architecture, like the wooden church built in 1764 in Petajavesi, included into the UNESCO World Heritage List. 
The northern towns of the country are also interesting for tourists: Rovaniemi, Kemijarvi, Ranua, Inari, Saariselska. These towns are well-known tourist centers of the country, located beyond the North Polar circle. The beauty of the northern nature, the Northern lights, plenty of ski resorts, winter residencies of the Finnish Santa Claus (Joulupukki) annually attracts thousands of tourists. The largest community in the country in Lapland, famous for the most world northern zoo in Ranua, the magic workshops of Santa Claus, the Northern Lights museum in Pohijan-Kruuny, and Deer Park in Salla (Topical news on Finland; Uusitalo, 2010; Sjoholm, 2014; Tervo-Kankare, Hall, \& Christmas, 2013).

The towns Lahti and Kuopio, municipalities Kuusamo and Muonio are the sports center of the country, where many international skiing events are held.

The majority of towns and municipalities in Finland offer large possibilities for rest: from visiting the architectural, historic and art monuments to the specific, sometimes exotic sites, like Snow Castle, Santa Claus residence, Mumintrolls' land, etc.

\section{Museums}

Finland attracts tourists with not only its wonderful northern nature, forests and lakes, but also its museums, exhibitions, and beautiful architecture. The museums of the country are thematically varied, which makes them interesting for both the connoisseurs of the ancient and modern history.

The majority of the museums can be attributed to two groups: cultural-historic and social-cultural museums. The applicability of such division is proved by the fact that the social-cultural museums mainly combine the cultural-historic environment with the modern socio-cultural practice. Among the examples are museums of toys, of transport, of snowmobiles and coffee cups in Kemijarvi and Tampere accordingly.

Another feature of Finnish museums is their thematic homogeneity in the regional aspect, which means that similar museums can be found in different regions of the country. This is because each town or municipality has its own history and traditions. Such museums are local history and art museums (13 and 21 museums accordingly). Territorially such museums are situated in different regions, but thematically they are the same. They show exhibits devoted to the history of the town, or pieces of art.

The majority of museums in large cities are available for tourists all the year round (Helsinki, Tampere, Turku, Kuopio, etc). In small towns and municipalities one can face seasonality and vacation activity.

The most interesting tourist attractions are: the National Museum of Finland in Helsinki; the Lenin Museum in Tampere; the museum of police and espionage in Tampere; Ateneum museum in Helsinki, which is the largest collection of classical art in Finland.

Also popular are: the museum of skiing and the museum of radio and television in Lahti, the unique scientific museum Eureka in Vantaa, Arktikum museum in Rovaniem, which shows the life and art of the northern peoples and artificial Northern Lights, Museum of Saami culture, showing the origin, culture and everyday life of the Sami, museum of dolls and costumes "Hatanpaa-kartano" in Tampere with over 4 thousand dolls from all over the world; museum of the history of gold and many others. Totally, 189 museums function in Finland, over 80 of them in the capital region.

\section{Cult Architecture (Churches, Temples, Cathedrals, Monasteries)}

Religion plays an important role in the life of the population. The majority of the citizens belong to two state religions: Lutheran (85\% of the believers) and Orthodox Christianity, which is due to the historic links with Sweden and Russia. These links are also reflected in the religious venues situated everywhere in the country (Jokela, 2014).

The majority of religious venues (the total number being 116) are churches, temples, cathedrals, monasteries.

The most significant of them are: Helsinki Cathedral; the Dormition Cathedral, which is the largest Orthodox temple in Scandinavia; Turku Cathedral, which is the main Lutheran church in Finland and the oldest temple in the country; Old church of Jyvaskyla, included into the UNESCO World Heritage List; the medieval St Laurence church in Lohja; the Orthodox St Nicolas church in Imatra; Chapel of Northern Lights, which is the only church in Lapland with a wooden cross made of 420 -year-old tree, and a number of other venues.

A lot of cult buildings have an ancient medieval history, dating back to the 17-19 cc. (Oulu Cathedral (1777), church in Hyrynsalmi (1786), Tornio church (1886)), with bright features of medieval wooden and stone architecture. 
Cathedrals in Helsinki, Turku, Dormition Cathedral, New Valaam, Lintulan nunnery, Lutheran Evangelical church in Rovaniemi are included into the excursion tours offered by tour operators in Finland.

\section{Venues of Medieval Architecture}

Venues of medieval architecture are a significant part of historical-cultural heritage of the country. Most of them have lost their defense function and became the monuments of excursion and cultural-entertaining purpose.

Castles, fortresses, ruins, well-preserved town districts (Old town) show the rich and complex history of Finland. There are 21 such venues.

The most attractive venues of that kind are: Kuusisto castle in Kaarina (Western Finland); Turku castle, one of the oldest medieval buildings in Finland; Svartholm fortress in Loviisa (Southern Finland); Hamina fortress; Old Towns in Turku, Naantali, Vaas, Rauma, Kokkola with their narrow paved streets and wooden houses. Kokkola historic buildings are one of the largest and best-preserved complexes of the northern wooden architecture.

Special attention should be paid to 2 historic buildings, which are included into the UNESCO World Heritage List: Suomenlinna fortress, one of the world largest sea fortresses, located on 8 islands, and Raum Old Town, a monument of wooden architecture comprising 600 constructions.

Like cult monuments, the mediaeval constructions are nowadays not used for their original purposes, but serve as sites for excursions, weddings, opera festivals (castles of Turku, Hame, Olavinlinn, etc.).

\section{Monuments of Industrial Architecture}

The problem of revealing, preserving and modern implementation of architectural monuments is topical for the industrial venues of Finland which possess both educational and historical-architectural value and require special approach to reconstruction and modern use.

Qualitatively and quantitatively the monuments of industrial architecture are a small group of mills, plants, tunnels and mines. 7 of them are the most interesting for tourists.

These are: Paasikiski mill in Puolanka municipality in Northern Finland, where different events are held in summer; the functioning amethyst mine in Luosto (Northern Finland), the only mine in Europe where precious stones are mined nowadays; the tunnel museum in Outokumpu (Eastern Finland), situated in the old mine and displaying exhibits connected with everyday life and work of miners; bunker museum in Joensuu municipality (Eastern Finland), which is the largest fortification museum in Scandinavia; metallurgy plant-museum Mohko in Illomantsi municipality, which shows the features of extraction and processing the ore in lakes, etc.

\section{Venues of City Construction and Architecture}

Venues of city construction and architecture in Finland are city halls and city districts, parks and gardens, stations and universities. They represent different historic epochs and combine the features of monumental, decorative, fine and landscape arts.

Though the city halls are mainly perceived as governmental structures, featuring strict colors and decorations in their interiors, some of them are used as leisure venues for the local residents and visitors.

The most well-known and notable city halls in Finland are city halls in Kajaani (1831), Oulu (1887), Tampere (1890), Pori (1841), Pauma (1776), Joensuu (1914), Porvoo (1764), Hamina (1798), Lappeenranta (1829) and the most known and visited city hall in Helsinki (1833), located in two central squares - the Senate and the Trade squares.

The city streets, districts, stations are a unique mixture of cultural-historic heritage and everyday life, from the most well-known fashionable trading quarters (Forum, Itäkeskus, Kamppi, Stockmann) and restaurants to the tourist centers, hotels and offices. Finland is a bilingual country, so all names of towns, distructs and streets are written in Finnish and Swedish.

The streets and avenues most interesting for the tourists are Bulevardi, Sofiankatu, Alekaterinkatu streets, Mannerheim avenue in Helsinki; Hameenkatu street in Tampere; Puu Nurmes and Vanha Kauppala Nurmes in the town of Nurmes in North Karelia; a number of other town streets, quarters and avenues.

Mannerheim Avenue is one of the main central streets in Helsinki, its longest avenue, which is $5.5 \mathrm{~km}$ long. It is a unique example of combining the cultural heritage and the modern life of the country, and its closeness to the Helsinki main railway station determines the mass visits of the city's guests. 
Sofiankatu Street, called "the museum street", illustrates how the Helsinki streets were built in 1800-1830-s. It begins from Senate Square and stretches south, to Kauppatori square, where Helsingin kaupunginmuseo is situated, which has 8 branches displaying the history of the Finnish capital.

The railway stations in Finland have rich history and are venues of cultural heritage of the region. The most well-known and interesting of the railway stations is the one in Helsinki. It is a monument if architecture and a large transportation nod in Finland. It was built in 1904-1914 by a Finnish architect Eliel Saarinen in art nouveau style. The station houses an entrance to metro station Rautatientori, the busiest station in the Helsinki metro.

The streets and avenues of Finnish towns are mainly marked with the typical northern minimalism and refinement together with functionalism.

\section{Sculpture Parks and Gardens}

Sculpture became well developed in Finland in the $19^{\text {th }} \mathrm{c}$, it was founded by a Swedish sculptor Carl Eneas Sjöstrand (1828-1906), the largest collector of Finnish epos. In 1880-1890-s sculpture becomes one of the leading artistic genres in Finland. Monuments to outstanding people are erected in towns, the park sculptures and reliefs for buildings are created. The main aim of sculpture was to propagate the national ideas: it is in those decades that the artistic orientation of the Finnish sculptors was formed.

The sculpture parks and gardens of Finland are unique outdoor exhibitions. They are sites of landscape design, either small in area, or occupying several dozens of hectares. The majority of them are public gardens, where the sculpture exhibition serves as an additional entertaining and esthetic element. The main purpose of parks is to popularize the modern art, as a lot more people visit parks than museums, which thus make additional advertisement for themselves.

The most well-known sculpture parks and gardens in Finland are:

- Karinimi park in Lahti. The main attraction is sculptures by Professor Olavi Lanu. A dozen of human silhouettes decorated as natural elements - stones and tree branches along a path.

- Veistopuisto sculpture park in Kotka, about 8 hectares large, which features sculptures by Finnish masters (a girl having rest, night pedestrians, a thunderstorm cloud). Annually the park obtains more sculptures, and in 2003 it got a prize of the Sculptors' Association of Finland - Pro Sculptura.

- Sculpture park in Imatra. The main theme here is sports competitions, athletes and gymnasts. There are about 500 human figures in various poses. Though very strange looking, thus park is famous all over the world. It is available for public free. In 2009 it was called the best tourist site in Finland.

Such art can cause various estimations, but the uniqueness and availability of these parks bring many tourists here, making them not only the excursion venues, but also recreation zones for the population.

Thus, the wealth and diversity of cultural-historic resources of Finland determine the features of cultural-historic tourist-recreational potential of the country, being the most important factor of the development of entrance tourism.

The data presented in the article can be used for organizing the tourist activity and predicting the tourist entrance flow.

\section{References}

Furmanov, K., Balaeva, O., \& Predvoditeleva, M. (2012). Tourism flows from the Russian Federation to the European Union. Anatolia: An International Journal of Tourism and Hospitality Research, (March), 17-31. http://dx.doi.org/10.1080/13032917.2011.653629

Honkanen, A. (2002). Churches and statues: Cultural tourism in Finland. Tourism and Hospitality Research, 4(April), 371-379.

http://www. unwto.org.

Jokela, S. (2014). Tourism and identity politics in the Helsinki churchscape. Tourism Geographies: An International Journal of Tourism Space, Place and Environment, 2, 252-269. http://dx.doi.org/10.1080/14616688.2013.865070

Kantanen, T., \& Tikkanen, I. (2006). Advertising in Low and High Involvement Cultural Tourism Attractions: Four Cases. Tourism and Hospitality Research, 6(February), 99-110. http://dx.doi.org/10.1057/palgrave.thr.6040049 
Kostiainen, J., \& Sotarauta, M. (2010). Great Leap or Long March to Knowledge Economy: Institutions, Actors and Resources in the Development of Tampere, Finland. European Planning Studies, 5, 415-438.

Lindsay, J. (2009). The Intrinsic Value of Cultural Heritage and its Relationship to Sustainable Tourism Development: The Contrasting Experiences of Jamaica and Japan. Caribbean Quarterly, 2(June), 151-168.

Murphy, C., \& Boyle, E. (2006). Testing a Conceptual Model of Cultural Tourism Development in the Post-Industrial City: A Case Study of Glasgow. Tourism and Hospitality Research, 2(February), 111-128. http://dx.doi.org/10.1057/palgrave.thr.6040050

Purhonen, S., Gronow, J., \& Rahkonen, K. (2011). Highbrow culture in Finland: Knowledge, taste and participation. Acta Sociologica, 4(December), 385-402. http://dx.doi.org/10.1177/0001699311422092

Remoaldo, P., Ribeiro, J., Vareiro, L., \& Santos, J. (2014). Tourists' perceptions of world heritage destinations: The case of Guimarães (Portugal). Tourism and Hospitality Research, 4(October), 206-218. http://dx.doi.org/10.1177/1467358414541457

Sjoholm, B. (2014). The Art of Recalling: Lapland and the Sami in the Art of Emilie Demant Hatt and Johan Turi. Feminist Studies, 2(Special Issue: Food and Ecology), 356-393.

Tervo-Kankare, K., Hall, M., \& Christmas, S. J. (2013). Tourists' Perceptions to Climate Change in Rovaniemi, Finland. Tourism Geographies: An International Journal of Tourism Space, Place and Environment, 2, 292-317. http://dx.doi.org/10.1080/14616688.2012.726265

Topical news on Finland.

Uusitalo, M. (2010). Differences in Tourists' and Local Residents' Perceptions of Tourism Landscapes: A Case Study from Ylläs, Finnish Lapland. Scandinavian Journal of Hospitality and Tourism, 3(January), 310-333. http://dx.doi.org/10.1080/15022250.2010.489786

Valle, P., Guerreiro, M., Mendes, J., \& Silva, J. (2011). The cultural offer as a tourist product in coastal destinations: The Case of Algarve, Portugal. Tourism and Hospitality Research, 4(October), 233-247. http://dx.doi.org/10.1177/1467358411420623

\section{Copyrights}

Copyright for this article is retained by the author(s), with first publication rights granted to the journal.

This is an open-access article distributed under the terms and conditions of the Creative Commons Attribution license (http://creativecommons.org/licenses/by/3.0/). 